\title{
The Amounts of Anti Trust Law in Indonesia
}

\author{
Alum Simbolon \\ Faculty of Law \\ University of Pelita Harapan \\ Medan, Indonesia \\ alum.simbolon@uph.edu
}

\begin{abstract}
Problem formulation in this research is what the amounts Anti-Trust law in Indonesia is. The purpose of the study is to analyze and see the amounts of Anti-Trust law in Indonesia. The research method used in this research is the normative juridical approach, namely legal research conducted by tracing, reviewing, researching secondary data relating to the material, and examining the condition in Indonesia by looking at the decision of the case conducted by KPPU. Results showed that conducive business climate can be implemented, monopolistic practices and or unfair business competition can be prevented by imposing and administrative sanction to the entrepreneurs violating provisions. To grow their business, entrepreneurs are prohibited from making prohibited contracts, banned activities, and abuse the dominant position. The sanctions stipulated in Article 47 of Law Number 5 Year 1999 concerning Ban on Monopolistic Practices and Unfair business competition.
\end{abstract}

Keywords-anti trust law; business competition supervisory commission (KPPU); entrepreneurs; banned activities; prohibited contracts; for abuse the dominant positions

\section{INTRODUCTION}

The presence of Law No. 5 of 1999 concerning Ban on Monopolistic Practices and Unfair Business Competition (UULPM) is welcomed by all relevant Indonesia, expecting to be well implemented by business players, KPPU and stakeholders [1]. UULPM is finally each college wants to enter this UULPM into a subject related to business law finally born the law course of Anti-Trust. In 2000, at the University of St. Thomas Catholic University, the faculty meeting when changing the curriculum it was questioned what the name of the course was related to this UULPM, and Mrs. Alum Simbolon called it Anti-Trust Law, after repeatedly reading UULPM, whatever inspiration helped my mind I finally called Business Competition Law. Soon some universities use the name of Business Competition Law course means there is the same thought, without any meeting to make the name of this course. It is conveyed that this UULPM which is applied in Anti-Trust Law, and which conducts supervision for the implementation of UULPM is the Business Competition Supervisory Commission (KPPU). Research on the amounts of Anti-Trust Law in Indonesia is to see the existence of the UULPM implementation which has a positive impact on the overall economic development of Indonesia based on KPPU's decision. KPPU's decision to sanction business players violating UULPM must pay a fine to the state as non-taxable income.
The objective of UULPM in Article 3 are to maintain public interest and improve the efficiency of the national economy as one of the means to improve public welfare, to create a conducive business climate through healthy AntiTrust, thus securing equal business opportunity for large, middle and small scale entrepreneurs or business players, to prevent monopolistic practices and/or unfair business competition by the entrepreneurs or business players, and to create effectiveness and efficiency in business activities. The noble objectives mentioned above expect to be well achieved with the supervision and enforcement of the law conducted by the Business Competition Supervisory Commission (KPPU), the Lawyers and other relevant parties, so that the goal of the welfare of the people and others will be achieved and the increase of economic growth will increased.

Indonesia is a developing country, and one of the characteristics of developing countries is development in all areas. The direction and policy pursued by the government basically rests on the Development Trilogy, with an emphasis on the equitable distribution of development and its outcomes in addition to efforts to achieve high economic growth and stable national stability [2]. Implementation of this UULPM will surely advance to economic growth by administering administrative sanctions to entrepreneurs or business players and ultimately the result of the fine goes to State's treasury as non-tax income. It is indeed beneficial for Indonesia the presence of UULPM with the supervision and law enforcement conducted by KPPU for each case examined and decided by KPPU in accordance with the duties and authority mandated by UULPM.

The duties and authorities of KPPU are regulated in Article 35 and 36 UULPM. The duties of KPPU are; conducting evaluations of contracts that might cause monopolistic practices and/or unfair business competition, conducting evaluations if there is any abuse or not in the dominant position that might cause monopolistic practices and/or unfair business competition, taking actions based on the authority of the KPPU (Article 35 of UULPM). KPPU's authority includes; receiving reports from the public and/or entrepreneurs concerning allegation of monopolistic practices and/or unfair business competition; conducting investigations on allegations of any business activity and/or actions by entrepreneurs or business players that might cause monopolistic practices and/or unfair business competition; conducting investigations and/or examination on allegation cases of monopolistic practices and/or unfair Anti-Trust; concluding the results of the 
investigation and/or examination whether there is any monopolistic practices and/or unfair business competition or not; summoning entrepreneurs or business players alleged to have violated the provisions; summoning and bringing witnesses, expert witnesses, obtaining, investigating and/or evaluating letters, documents, or other evidence for the purpose of investigation and/or examination; notifying the KPPU's decision to the entrepreneurs or business players alleged of conducting monopolistic practices and/or unfair business competition; imposing and administrative sanction to the entrepreneurs violating provisions (Article 36 UULPM).

The utilitarian philosophy that everything should reflect its utility influences the juristic mindset of the law. Utilitarian's see the law as a tool for the greatest happiness for the greatest number in the public law of punishment is no longer regarded as defamation, but is seen to function as a deterrent effect in order to infringe or crime that the same is not repeated in the future by others then after the punishment for the same offense can be prevented. To achieve that goal [3]. For a State that wishes to eliminate or at least reduce the concentration of economic activities based on unfavorable market conditions and full of fraudulent anti-monopoly laws is a very important and valuable one [4]. This UULPM changed the behavior of business players in carrying out their business activities, such as KPPU Decision Number 26 / KPPU-L / 2007 about Short Messaging Services (SMS) Cartel, the community can enjoy the KPPU's decision by decreasing SMS price and business actor to change his behavior [5].

The authors state that the utilitarian view which sees the law as a means to achieve happiness, the greatest happiness is expected from the implementation of this UULPM so that the enforcement of competition law can be achieved and the fine result into the State treasury. The amounts of UULPM presence in the law of Anti-Trust in Indonesia is needed, business players can run the business activities without harming other business players and also without harming the state and society. Anti-Trust Law in every country is very needed and each role well for the existence of control for every business actor in running its business activity. The problem in this research is anti-trust law is important in Indonesia. The purpose of the research is to analyze and know the amounts of competition law in Indonesia

\section{METHOD}

The research method used in this research is the normative juridical approach, namely legal research conducted by tracing, studying, researching secondary data related to research material, and examining the condition in Indonesia by looking at the decision of a case conducted by KPPU.

\section{RESUlT AND DisCUSSION}

Show that the importance of the Business Competition Law in Indonesia is with the multitude of the Decision of the KPPU since standing KPPU is less more than 300 verdict issued by the KPPU. With the existence of the verdict against the things that come to the KPPU and examinations and disconnected by the KPPU, this shows that the law of the Business Competition is revealed important for Indonesia. From the decision of the matter which is done by the KPPU to impose administrative sanctions as sanctions, then there is a company that must pay a fine, there is a company that should be canceled the agreement made in accordance with the mandate of Article 47 UULPM. In this competition law enforcement by KPPU certainly experience obstacles such as filing an objection to the District Court, objections to whom because there must be parties because KPPU is a party or not party. KPPU deciding business competition case in the first level, this is an obstacle and in the end KPPU is made as a party [6]. Competition In the business world to get maximum profit comes in various forms, e.g. in price, quantity, service or combination of various players that will be assessed by the consumer [7].

The following describes a case that was cut off by KPPU namely Yamaha and Honda Case Cartel as follows: Through various series of investigations in the scooter motorcycle industry, Business Competition Supervisory Commission (KPPU) smell business practices unhealthy motorcycle sales allegedly conducted by two giant automotive companies, namely PT Yamaha Indonesia Motor Manufacturing (YMMI) and PT Astra Honda Motor (AHM). On Wednesday, (19/7/2016), KPPU held a preliminary hearing session led by Tresna P. Soemardi, with members of the Misanam Munkhim assembly and R. Kurnia Sya'ranie. Chairman of KPPU, M. Syarkawi Rauf said that the alleged existence of the violation is based on the existence of coordination or conspiracy in determining the selling price of motorcycle scooter matic type 110-125 CC in Indonesia. Based on data from the Indonesian Motorcycle Industry Association (AISI), there are Honda (AHM), Yamaha (YMMI), and PT Suzuki Indomobil Motor (Suzuki) and PT TVS Motor Company Indonesia (TVS). Of the four manufacturers, Honda and Yamaha control approximately 97 percent of the motor market scooter. In fact, in recent years, Honda led schooter motorcycle market in the homeland. The process of investigation of this initiative has been conducted by KPPU since 2014, especially the matic type. The market in the bicycle matic industry is controlled by the two manufacturers. In addition to the dominant scooter market dominance of the two manufacturers, KPPU also found a price movement, schooter motorcycle type Yamaha and Honda are in tandem. Motor scooter price increase Yamaha always follow the price increase motor scooter Honda [8].

Saidah Sakwan as member of KPPU explained that the automatic scooter motorcycle should be sold in Rp. 8.7 million in Indonesia market. But both reportedly sell it for Rp. 14-18 million. This is according to Saidah, very profitable company. In this case, the KPPU investigator previously found an irregularity in the price of motorcycle, scooter matic 110-125 CC PT Yamaha Indonesia Motor Manufacturing and PT Astra Honda Motor. KPPU suspects the two companies to discuss the agreement between PT Yamaha Indonesia Motor Manufacturing will follow the selling price of PT Astra Honda Motor. This agreement is then followed up by the order via electronic mail that in the end there is adjustment of product selling price of PT Yamaha Indonesia Motor Manufacturing following the sale price of PT Astra Honda Motor. There are three evidences to be considered by the Commission Council: A meeting on the golf course; Yamaha internal email 
communication; and motorcycle price hike and price parallelism [9].

The price increase, with a span of several hundred thousand rupiah in the period referred to SERTA price parallelism as evidence of the dispute. Price parallelism. KPPU declared price parallelism or price fluctuation parallel between Yamaha and Honda. Yet, as stated by an expert witness who is also a former Commissioner of KPPU, Dr. Faisal Basri, the phenomenon of price parallelism is by no means caused by cartel practices. In a healthy competitive market, there can be a tight price trend as a result of the efficiency of competing competitors [10].

An assembly commission of the trial led by Tresna Priyana Soemardi and members, R Kurnia Sya'ranie and Munrokhim Misanam, assess all elements in UULPM Article 5 has been fulfilled. Finally, the decision of the commission's council was YIMM and AHM proven legally and convincingly violating UULPM Article 5 of 1999. The Commission Assembly also sentenced YIMM with a fine of Rp 25 billion and AHM of Rp 22.5 billion. The fines received by YIMM are heavier with the assessment of the commission assembly for having manipulated the data in the hearing. Therefore, the penalty for YIMM includes 50 percent of the proportion of fines. While the penalty imposed for AHM has been cut 10 percent as assessed cooperatively by the panel of judges.

UULPM Article 5, paragraph 1, very clearly prohibits such practices. Entrepreneur is prohibited from entering into an agreement with a competing business actor to fix the price of a good or service to be paid by a consumer or customer in the same relevant market. KPPU Commission Regulation No. 4 of 2011 on guidance of article 5, explains, price fixing is prohibited because it always yields a price far above the price through fair business competition. This high price of course causes the loss to consumers, directly or otherwise. The condition of fair competition, motorcycle prices will be pushed down near the cost of production. As prices move down near the cost of production, the market will become more efficient, the effect will increase the savings for consumers (welfare improvement).

The seriousness of KPPU is guarding UULPM and realizing that it is better to work together with other parties, KPPU cooperates with several universities and law enforcement agencies, along with KPPU Partners: Nahdlatul Ulama; University of Islam Indonesia; University of Sumatera Utara; University of Sam Ratulangi; University of Andalas; University of Hasanuddin; University of Padjadjaran; University of Brawijaya; University of Airlangga; University of Diponegoro; University of Gajah Mada. Then, with several law enforcement agencies such as: Police of the Republic of Indonesia; SOP POLRI; Commission of corruption Eradication; Attorney General of the Republic of Indonesia). According to the author of the above fact is very important presence of Anti-Trust law for the Republic of Indonesia.

\section{CONCLUSION}

The amounts of Anti-Trust Law in Indonesia is to solve business competition cases and control the behavior of business players who run the business activities if there are unfair ones. And this is evidenced by the many cases of business competition submitted to the KPPU both in the form of reports and because of KPPU's initiative. With the verdict in cases that entered the KPPU and conducted an examination and decided by KPPU, this shows that the Business Law is very declared important for Indonesia. From the decision of the case conducted by KPPU such as the cartel case between Yamaha and scooter Honda above, YIMM was fined Rp 25 billion and AHM Rp 22.5 billion. KPPU impose administrative sanction such as penalty, sanction, then there are companies that have to pay a fine, there is a company that must be canceled the agreement done in accordance with Article 47 UULPM although still can be filed objection to KPPU decision the Court. Demonstrating the amounts of Anti-Trust Law, its implementation and law enforcement are done by KPPU, seen from its many partners of KPPU to improve people's welfare, in implementing UULPM.

\section{ACKNOWLEDGEMENT}

The author would like to thank all the parties who have helped and contributed in the writing of this article, both those who contribute in the form of funding and critical ideas. Hopefully this paper can be useful theoretically and practically for the addition and development of knowledge, especially in the field of legal science.

\section{REFERENCES}

[1] S. Alum, Hukum Persaingan Usaha, First Edition, Liberty, Yogyakarta. 2014.

[2] P. Nindyo, Sertifikat Saham Go Publik dan Hukum Pasar Modal di Indonesia. Citra Aditya Bakti, Bandung. 1997.

[3] Shenefield, J. H., and Stelzer, I. M., The Anti Trust law A Primer, Fourth Edition The American Enterprice Institute, Washinton, DC, 2001 .

[4] Kagramanto, B. L., Larangan Persekongkolan Tender (Perspektif Hukum Persaingan Usaha), Srikandi, Surabaya, 2008.

[5] S. Alum, 'Hambatan yang Dihadapi Komisi Pengawas Persaingan Usaha (KPPU) dalam Implementasi Hukum Persaingan Usaha', Jurnal Hukum Bisnis. Vol. 31 No. 5. ISSN 2301 9190, Accredited, Jakarta, 2012.

[6] S. Alum, Kedudukan Hukum Komisi Pengawas Persaingan Usaha Melaksanakan Wewenan Penegakan Hukum Persaingan Usaha. Jurnal Mimbar Hukum, Vol. 24, No. 3, Faculty of Law, Universitas Gadjah Mada. ISSN 0852100X, Accredited, Yogyakarta. 2012.

[7] S. Alum, Pendekatan Yang Dilakukan Komisi Pengawas Persaingan Usaha Menentukan Pelanggaran dalam Persaingan Usaha, Jurnal Ius Quia Iustum, Vol. 20 No. 2, ISSN 0854 8498. Faculty of Law, Universitas Islam Indonesia. Accredited, Yogyakarta. 2013.

[8] Kobayogas, Yamaha dan Honda Hadir dalam Sidang Dugaan Kartel Skutik di KPPU, access on March, 27th 2018, at 4:04pm <http://kobayogas.com/2016/07/20/yamaha-dan-honda-hadir-dalamsidang-dugaan-kartel-di-kppu/> 2016.

[9] G. Prima, KPPU: Yamaha-Honda Bersekongkol Permainkan Harga Skuter Matik, CNN Indonesia, 2017.

[10] Leo, Ketidak-hati-hatian KPPU dalam Memutus Dugaan Kartel Yamaha-Honda, access on March, 27th 2018, at 4:11pm, <https://7leopold7.com/2017/02/21/ketidak-hatihatian-kppu-dalammemutus-dugaan-kartel-yamaha-honda/> 2017. 